\title{
Variations in biochemical attributes of Cassia tora L. and C. auriculata L. under temperature stress
}

\author{
Geetika Pant ${ }^{1}$, Sibi G. ${ }^{1}$, Sangeetha Annie George ${ }^{2}$, Shubha Bhadran ${ }^{3}$, Ugam Chauhan ${ }^{4}$ \\ ${ }^{1}$ Department of Biotechnology, Indian Academy Degree College, Centre for Research and Post Graduate Studies, Bangalore, INDIA \\ ${ }^{2}$ Department of Zoology, Indian Academy Degree College, Centre for Research and Post Graduate Studies, Bangalore, INDIA \\ ${ }^{3}$ Department of Genetics, Indian Academy Degree College, Centre for Research and Post Graduate Studies, Bangalore, INDIA \\ ${ }^{4}$ Department of Biotechnology, A. P. S. University, Madhya Pradesh, INDIA
}

\section{Email address:}

way2geetika@gmail.com (Geetika P.)

\section{To cite this article:}

Geetika Pant, Sibi G., Sangeetha Annie George, Shubha Bhadran, Ugam Chauhan. Variations in Biochemical Attributes of Cassia tora L. and C. auriculata L. under Temperature Stress. American Journal of Life Sciences. Special Issue: Recent Developments in Health Care through Plants and Microbes. Vol. 2, No. 6-1, 2014, pp. 16-21. doi: 10.11648/j.ajls.s.2014020601.14

\begin{abstract}
Plants continuously struggle for survival under various environmental abiotic stress conditions, specifically high temperature. Fourteen-day-old seedlings of Cassia tora and Cassia auriculata were subjected to differential temperature stress treatments at $30^{\circ} \mathrm{C}, 37^{\circ} \mathrm{C}, 42^{\circ} \mathrm{C}$ and $44^{\circ} \mathrm{C}$ for $16 \mathrm{~h}$ each. Various biochemical parameters viz reducing sugars, total protein, chlorophyll content and antioxidant enzyme system were assessed and found to be increased under high temperature stress. The amount of reducing sugars, total protein and chlorophyll were remarkably increased in both the Cassia species at $42^{\circ} \mathrm{C}$. The POX activity was more profound in C. tora $(0.41 \mathrm{U} / \mathrm{mg})$ than C. auriculata $(0.24 \mathrm{U} / \mathrm{mg})$ at $42^{\circ} \mathrm{C}$. However, the activity of Catalase in both the species recorded a similar effect with a maximum value of 0.39 and $0.43 \mathrm{U} / \mathrm{mg}$ in C. tora and C. auriculata respectively. Similarly, SOD percentage inhibition activity increased significantly at $42^{\circ} \mathrm{C}$ for C. tora and C. auriculata showing a noticeable trend of inhibition of $85.23 \%$ and $86.89 \%$ respectively. Thus it can be concluded that various osmolytes and an efficient antioxidative system play a key role in generating tolerance against temperature stress and maintaining homeostasis to withstand the maximum range for survival at $42^{\circ} \mathrm{C}$ in Cassia seedlings.
\end{abstract}

Keywords: Cassia tora, Cassia auriculata, Temperature Stress, Reactive Oxygen Species, Antioxidant Enzymes

\section{Introduction}

Abiotic stress is the primary cause of crop loss worldwide, reducing average yields for most of the major plants by more than $50 \%$ [1]. Plants in the field are frequently subjected to this stress that adversely affects their growth, development, and productivity [2-4]. Drought and heat stress are the common factors causing the most severe damage [5-8]. Among the ever-changing components of the environment, the constantly rising ambient temperature is considered to be one of the most detrimental stresses. High temperature stress induces morphological [9], anatomical [10] as well as physiological and biochemical changes in plants. It induces the changes in water relations [11-13], accumulation of compatible osmolytes [14, 15], and decrease in photosynthesis [16]. Besides this, high temperature also induces the rapid production and accumulation of reactive oxygen species
(ROS) $[17,18]$. These high levels of ROS are harmful to all cellular compounds and negatively influence cellular metabolic processes [19]. The detoxification of these ROS is very important and plants have developed complex strategies to deal with them [20]. The plant cells typically respond to increases in ROS levels by increasing the expression and activity of ROS-scavenging enzymes and increasing their production of antioxidants in order to maintain redox homeostasis.

Cassia, an ancient Greek reference to several leguminosae plants [21] is prized for its medicinal virtues and edible quality. Due to its medicinal, agricultural, and economic importance, Cassia has drawn the attention worldwide. The two important members of Cassia known for their prized, ayurvedic medicinal values are Cassia tora L. (Syn. C. obtusifolia L.) and Cassia auriculata L. C. tora, also called ringworm plant, is widely used as a source of medicine for constipation, conjunctival congestion, and blurred vision. The leaves possess hepatoprotective activity 
[22]. The paste of the ground, dried root of C. tora is used in Ayurveda as a treatment for ringworm and snakebite [23]. It has also proven its worth in piles or haemorrhoids [24]. Besides being used as a medicinal herb, seeds are used as a substitute for coffee bean and mordant for dying and tanning [25]. On the other hand, C. auriculata commonly known as "Tanners Cassia," is widely used in traditional medicines for curing rheumatism, conjunctivitis, and diabetes. Studies also revealed anti-cancer effect of the leaf extract of $C$. auriculata (in vitro) on human breast and larynx cancer [26]. The plant also has anti-peroxidative efficacy in its flower extract [27].

In context to this, much of the reported works related to $C$. tora and $C$. auriculata have been focused on their medicinal aspects and there is a dearth of information on the effect of high temperature stress in the given plants at the biochemical levels. Hence, the present study was conducted to evaluate the effect of high temperature stress tolerance on reducing sugars, total protein, chlorophyll and antioxidant scavenging enzyme system for the two Cassia species.

\section{Materials and Methods}

\subsection{Sample Collection and Identification}

Disease-free and healthy pods of C. tora and C. auriculata were collected from the local populations around Bangalore during July 2012 and seeds were separated.

\subsection{Preparation of Planting Material}

Tetrazolium test for seed viability was conducted to estimate the seed germinability [28]. Seeds were cleaned with running tap water and surface-sterilized by fungicide (Rhedomyl) to prevent fungal contamination. The sterilized seeds were sown in plastic pots (6") filled with red soil, sand and Farm Yard Manure $(1: 2: 1)$ and allowed them to germinate for 2 weeks in green house. Fourteen-day-old seedlings were subjected to differential temperature stress treatments of $30^{\circ} \mathrm{C}, 37^{\circ} \mathrm{C}, 42^{\circ} \mathrm{C}$ and $44^{\circ} \mathrm{C}$ for $16 \mathrm{~h}$ each. One set of experiment remained at ambient temperature $\left(25 \pm 2^{\circ} \mathrm{C}\right)$ as a control. A completely randomized design with three replicates for temperature stress and ten seeds per replicate was taken for the study.

\subsection{Biochemical Analysis}

Both the stressed and control plants were analyzed for different biochemical parameters, viz. chlorophyll, protein estimation, reducing sugar and antioxidant enzyme assay for Superoxide dismutase (SOD), Peroxidase (POX), and Catalase (CAT) at different temperature treatments.

\subsubsection{Chlorophyll and Total Protein Estimation}

Chlorophyll $(a, b)$ and total protein was estimated according to the methods described by Arnon [29] and Lowry et al. [30] respectively.

\subsubsection{Reducing Sugar Estimation}

The reducing sugar was estimated as per the method suggested by Ranganna [31].

\subsubsection{Antioxidant Enzyme Extractions and Assay}

The antioxidant enzyme activity was conducted for three enzymes, viz. POX, CAT and SOD, at varying temperature stress conditions in both the species following the previous methods [32-34] with few modifications.

\subsubsection{Peroxidase (POX) Assay}

POX was assayed by the method of Kumar and Khan [32]. Assay mixture of POX contained $2 \mathrm{ml}$ of $0.1 \mathrm{~mol} / \mathrm{L}$ phosphate buffer ( $\mathrm{pH} 6.8$ ), $1 \mathrm{ml}$ of $0.01 \mathrm{~mol} / \mathrm{L}$ pyrogallol, 1 $\mathrm{ml}$ of $0.005 \mathrm{~mol} / \mathrm{L} \mathrm{H}_{2} \mathrm{O}_{2}$ and $0.5 \mathrm{ml}$ of enzyme extract. The solution was incubated for $5 \mathrm{~min}$ at $25^{\circ} \mathrm{C}$ after which the reaction was terminated by adding $1 \mathrm{ml}$ of $2.5 \mathrm{~mol} / \mathrm{L} \mathrm{H}_{2} \mathrm{SO}_{4}$ The amount of purpurogallin formed was determined by measuring the absorbance at $420 \mathrm{~nm}$ against a blank prepared by adding the extract after the addition of 2.5 $\mathrm{mol} / \mathrm{L} \mathrm{H}_{2} \mathrm{SO}_{4}$ at zero time. The activity was expressed in $\mathrm{U} / \mathrm{mg}$ protein. One $\mathrm{U}$ is defined as the change in the absorbance per $0.1 \mathrm{~min}$ per $\mathrm{mg}$ protein.

\subsubsection{Catalase (CAT) Assay}

The activity of CAT was measured according to the method of Chandlee and Scandalios [33]. The assay mixture contained $2.6 \mathrm{ml}$ of $50 \mathrm{mM} / \mathrm{L}$ potassium phosphate buffer ( $\mathrm{pH} 7.0$ ), $0.4 \mathrm{ml}$ of $15 \mathrm{mM} / \mathrm{L} \mathrm{H}_{2} \mathrm{O}_{2}$ and $0.04 \mathrm{ml}$ of enzyme extract. The decomposition of $\mathrm{H}_{2} \mathrm{O}_{2}$ was followed by the decline in absorbance at $240 \mathrm{~nm}$. The enzyme activity was expressed in $\mathrm{U} /(\mathrm{mg}$ protein). One $\mathrm{U}$ is defined as $1 \mathrm{mM} / \mathrm{L}$ of $\mathrm{H}_{2} \mathrm{O}_{2}$ reduction per min per $\mathrm{mg}$ protein.

\subsubsection{Superoxide Dismutase (SOD) Assay}

The activity of SOD was assayed as described by Beauchamp and Fridovich [34]. The reaction mixture contained $1.17 \times 10^{6} \mathrm{~mol} / \mathrm{L}$ riboflavin, $0.1 \mathrm{~mol} / \mathrm{L}$ methionine, $2 \times 10^{5} \mathrm{~mol} / \mathrm{L} \mathrm{KCN}$ and $5.6 \times 10^{5} \mathrm{~mol} / \mathrm{L}$ nitroblue tetrazolium (NBT) salt dissolved in $3 \mathrm{ml}$ of $0.05 \mathrm{~mol} / \mathrm{L}$ Sodium Phosphate buffer ( $\mathrm{pH}$ 7.8). Three millilitres of the reaction medium was added to $1 \mathrm{ml}$ of enzyme extract. The mixtures were illuminated in glass test tubes by two sets of Philips $40 \mathrm{~W}$ fluorescent tubes in a single row. Illumination was started to initiate the reaction at $30^{\circ} \mathrm{C}$ for $1 \mathrm{~h}$. Identical solutions that were kept under dark served as blanks. The absorbance was read at $560 \mathrm{~nm}$ in the spectrophotometer against the blank. SOD activity is expressed in $\mathrm{U} /(\mathrm{mg}$ protein). One $\mathrm{U}$ is defined as the change in 0.1 absorbance per hour per mg protein.

The percent inhibition of the sample was calculated by using the following formula.

$$
\text { Inhibition (\%) }=\frac{\left(\text { Blank }_{\mathrm{A} 560}-\text { Test }_{\mathrm{A} 560}\right)}{\text { Blank }_{\mathrm{A} 560}} \times 100
$$

\subsection{Statistical Analysis}

Data was recorded for all the biochemical parameters and were analysed by two way ANOVA and confirming the result 
by Tukey's Test using the statistical software (SYSTAT VER. 0.6) to assess the effect of temperature stress on both the species of Cassia. All the acquired data was represented by an average of three replicate measurements and standard error. Significance was tested at 5\% level.

\section{Results}

Different biochemical parameters, viz. reducing sugar, total protein, chlorophyll $a$ and $b$, and antioxidant enzymes, Peroxidase (POX), Catalase (CAT), and Superoxide dismutase (SOD) were evaluated in two species of Cassia at varying temperature treatments. All the biochemical attributes studied in the Cassia seedlings exhibited significant responses with increase in temperature stress.

Post hoc comparisons using the Tukey HSD test indicated that the mean score for the control was significantly different from $37^{\circ} \mathrm{C}$ and $42^{\circ} \mathrm{C}$. However, the temperature $30^{\circ} \mathrm{C}$ did not differ significantly from control. In both the species of Cassia, the concentration of reducing sugars, total proteins and level of chlorophyll significantly increased with increase in temperature. Our results suggested that as the temperature was increased from $30^{\circ} \mathrm{C}$ to $42^{\circ} \mathrm{C}$, the amount of reducing sugar concentration levels also increased from $0.11-0.71$ and $0.09-0.91 \mu \mathrm{g} / \mu \mathrm{l}$ in $C$. tora and $C$. auriculata respectively (Fig-1). Similarly, the amount of total protein content under temperature stressed seedlings in both the Cassia spp. was found to be maximum with a value of 4.67 and $4.34 \mu \mathrm{g} / \mu \mathrm{l}$ at $42^{\circ} \mathrm{C}$ (Fig-2). A significant increase in leaf chlorophyll content was observed in both plant species compared with control, and the maximum increase was measured at $42^{\circ} \mathrm{C}$ (Fig-3 and 4).

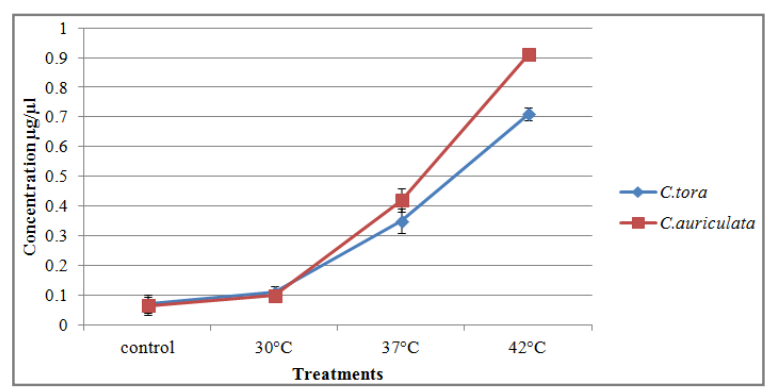

Fig 1. Effect of different temperatures on reducing sugar content of C. tora and $C$. auriculata plantlets

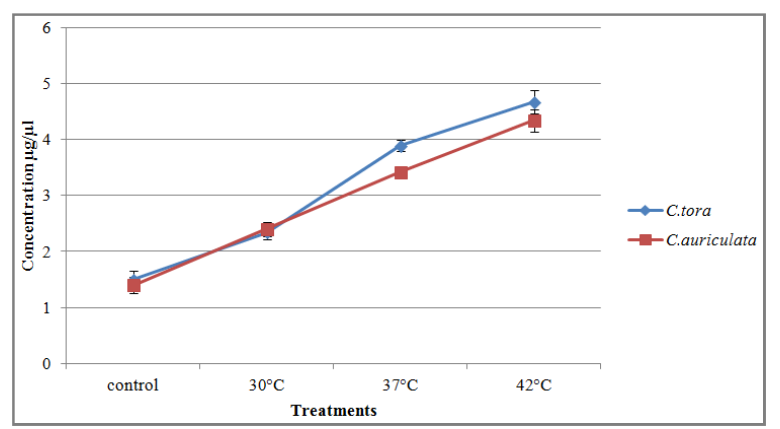

Fig 2. Effect of different temperatures on protein content of C. tora and C. auriculata plantlets

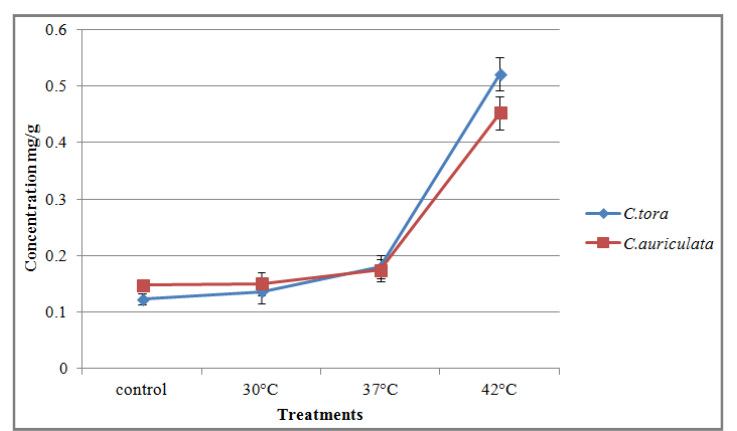

Fig 3. Effect of different temperatures on chlorophyll a content of C. tora and C. auriculata plantlets

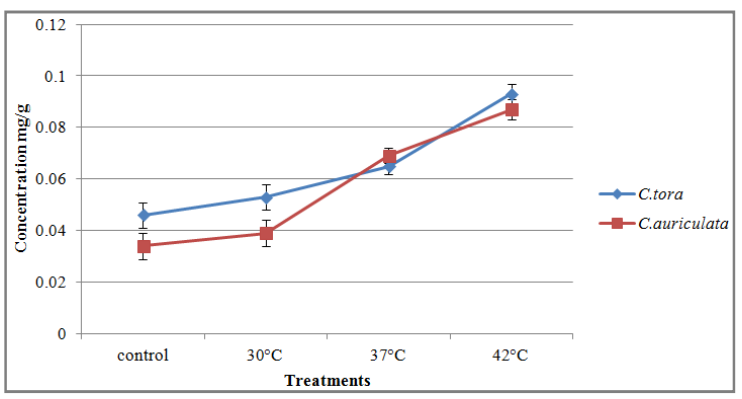

Fig 4. Effect of different temperatures on the chlorophyll b content of $C$. tora and C. auriculata plantlets

Quantitative and qualitative alterations in various antioxidant enzymes and its system are mostly related to the tolerance level of a plant species for a particular stress. Temperature stress in Cassia seedlings altered the POX, CAT and SOD activities to a great extend. The gradual increase of temperature stress to $42^{\circ} \mathrm{C}$ recorded the maximum activity. At $37^{\circ} \mathrm{C}$ and $42^{\circ} \mathrm{C}$, Cassia seedlings showed a remarkable increase in the activity for POX and CAT enzymes at high temperature; however, the POX value was just about double in C. tora $(0.41 \mathrm{U} / \mathrm{mg})$ than $C$. auriculata $(0.24 \mathrm{U} / \mathrm{mg})$ at $42{ }^{\circ} \mathrm{C}$ (Fig-5). However, the activity of Catalase in both the species recorded a similar effect with a maximum value of 0.39 and $0.43 \mathrm{U} / \mathrm{mg}$ in C. tora and C. auriculata respectively. The CAT effect revealed a gradual increase in its activity unlike POX (Fig-6). Total SOD percentage inhibition activity increased significantly at $42^{\circ} \mathrm{C}$ for Cassia tora and $C$. auriculata showing a noticeable trend of inhibition at $85.23 \%$ and $86.89 \%$ respectively. Compared to control (unstressed) plants had the minimum value for this enzyme (57\%) (Fig-7).

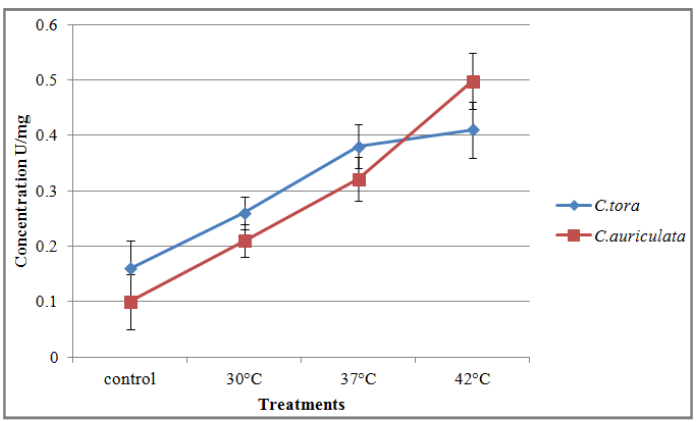

Fig 5. Effect of different temperatures on POX activity of C. tora and C. auriculata plantlets 


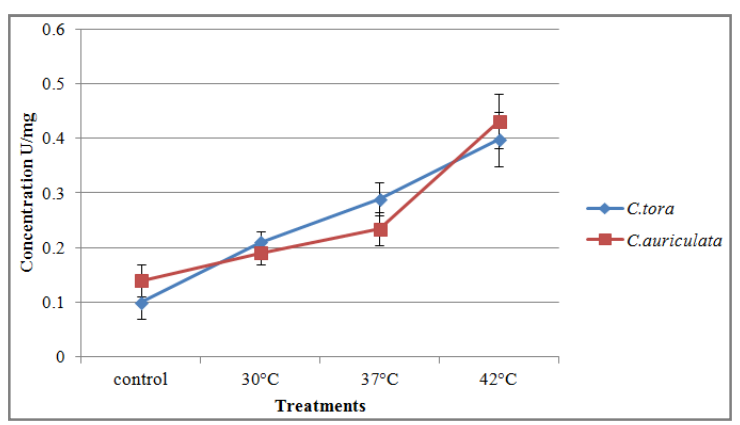

Fig 6. Effect of different temperatures on CAT activity of C. tora and C. auriculata plantlets

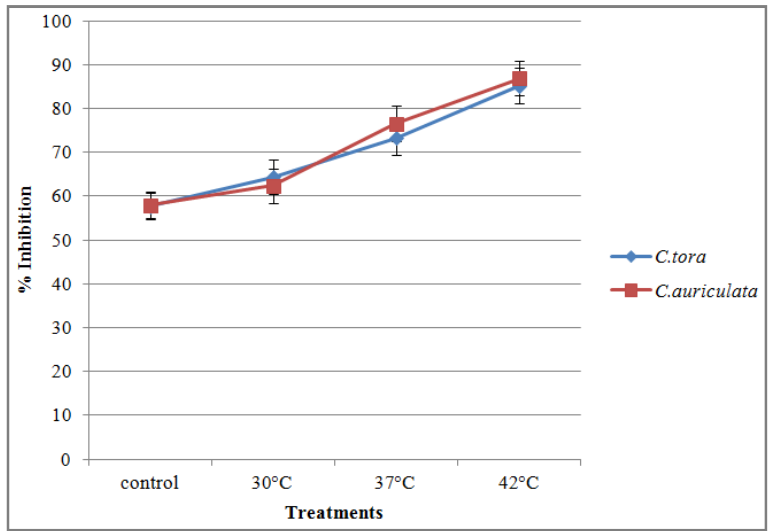

Fig 7. Effect of different temperatures on SOD activity of C. tora and C. auriculata plantlets

\section{Discussion}

In nature, plants resort to various acclimation strategies in response to abiotic environmental stresses like high temperature, dehydration, cold and excessive osmotic pressure [35]. This effect results in series of changes at physiological and biochemical levels like those encoding scavenging antioxidant enzyme system, chlorophyll value, sugar and protein content in a plant. Accumulation of total soluble sugars is a common phenomenon under stress condition [36, 37]. Our results indicates increased reducing sugar concentration levels in both the Cassia species with an increase in temperature, which is in agreement with the work done by Nayar et al., [38] in chickpea seedlings. In the present study, Cassia tora and C. auriculata accumulated more sugars which are effective in maintaining turgor pressure and showing higher osmotic adjustment in the given plants. It has been documented that sucrose plays a positive role in protecting cells from injuries under cold or high temperature in some plants [39] which is seen in both the Cassia species.

Under temperature stress, variation in the transcript and enzyme levels of major antioxidant enzymes during stress is well documented. Our result suggests that as the temperature was increased the concentration of total soluble protein levels increased from $30^{\circ} \mathrm{C}$ to $42^{\circ} \mathrm{C}$. The reduction in protein content may reflect delay in protein synthesis which accelerates its degradation. According to the increase in the amount of free amino acids in the protein, the increased values observed in the case of $C$. tora and $C$. auriculata from $30^{\circ} \mathrm{C}$ to $42^{\circ} \mathrm{C}$ could be related to the period of active multiplication of plants and consequently higher protein synthesis, thus protecting the seedlings from degradation even at the maximum temperature stress. Similar findings were supported by Isabela et al., [40] in sugarcane seedlings.

Chlorophyll content in plants is an important trait to assess photosynthetic efficiency under varying stressed conditions. High-temperature stress directly or indirectly affects plant photosynthetic functions by changing the structural organization and physicochemical properties of thylakoid membranes [41]. In the present study, an increased level of chlorophyll $\mathrm{a}$ and $\mathrm{b}$ was observed in Cassia seedlings subjected to heat stress at $42^{\circ} \mathrm{C}$ for $16 \mathrm{~h}$. which is in agreement with Gur et al. [42] in cotton. The plants exposed to extreme temperatures result in production of reactive oxygen species (ROS) as byproducts, which damage the cellular components [43]. Plants have developed a series of enzymatic and non-enzymatic detoxification systems to counteract ROS and protect cells from oxidable damage [44].The antioxidant enzymes such as SOD, CAT, POX, function in detoxification of superoxide and $\mathrm{H}_{2} \mathrm{O}_{2}$ [17]. When plants are subjected to various stress, the first ROS scavenging enzyme active and participating in the enzymatic mechanism is SOD. Super oxide dismutases active oxygen radicals into $\mathrm{H}_{2} \mathrm{O}_{2}$ and plays an important role in cell defense system against ROS [45]. The $\mathrm{H}_{2} \mathrm{O}_{2}$ generated is further scavenged by other two important enzymes CAT and POX. The protective roles of these antioxidant enzymes in temperature stress have been reported in a number of plants [46]. In the present work, total SOD inhibition percentage, CAT and POX enzymes increased with higher temperature stress. Similar results were found in French bean [47]. Our results are also in agreement with heat stressed mustard suggested by Dat et al, [48]. Increased activity of CAT, POX, and SOD has been suggested as an adaptive mechanism to reduce the $\mathrm{H}_{2} \mathrm{O}_{2}$ and offer protection against oxidative damage [49] which is significantly observed in Cassia.

\section{Conclusion}

The assessment of the temperature stress on various biochemical attributes in Cassia tora and C. auriculata seedlings lead us to conclude that all the parameters in consideration revealed a significant effect under temperature stress. The results point out that, high temperature provoked all the biochemical parameters and free radical scavenging enzymes, contributing in making the plant higher temperature tolerant which is essential for the plant growth and its productivity in extreme temperature conditions. This may also permit to understand plant survival capacity following ecological disturbances in the vicinity. Further, the genes playing role in heat tolerance and identification of markers encoding 
scavenging properties would be another step towards developing a better responding Cassia species under elevated temperature.

\section{References}

[1] W. Wang, B. Vinocur, A. Altman, "Plant responses to drought, salinity and extreme temperatures towards genetic engineering for stress tolerance," Planta, vol. 218, 1-14, 2007.

[2] M.M. Chaves, J.P. Maroco, J.S. Pereira, "Understanding plant responses to drought from genes to the whole plant," Funct. Plant Biol., vol. 30, 239-264, 2003.

[3] S. Kotak, E. Vierling, H. Baumlein, P. Von Koskull-Doring, "A novel transcriptional cascade regulating expression of heat stress proteins during seed development of Arabidopsis," Plant Cell, vol.19, 182-195, 2007a.

[4] S. Kotak, J. Larkindale, U. Lee, P. Von Koskull-Doring, E. Vierling, K.D. Scharf, "Complexity of the heat stress response in plants, "Curr. Opin. Plant Biol, vol. 10, 310-316, $2007 b$.

[5] W. Wang, B. Vinocur, O. Shoseyov, A. Altman, "Role of plant heat shock proteins and molecular chaperons in the abiotic stress response," Trends in plant Science. vol. 9, 244252, 2004.

[6] K.V. Sumesh , P. Sharma-Natu, M.C. Ghildiyal, "Starch synthase activity and heat shock protein in relation to thermal tolerance of developing wheat grains," Biol. Planta. vol.52, 749-753, 2008.

[7] M.G Santos, R.V. Ribeiro, E.C. Machado, C. Pimentel, "Photosynthetic parameters and leaf water potential of five common bean genotypes under mild water deficit," Biol. Planta., vol. 53, 2009, pp. 229-236, 2009.

[8] B. Grigorova, I. Vaseva, K. Demrievska, U. Feller, "Combined drought and heat stress in wheat: changes in some heat shock proteins" Biol. Planta., vol. 55, 105-111, 2011.

[9] C.D. Giaveno, J. Ferrero, "Introduction of tropical maize genotypes to increase silage production in the central area of Santa Fe, Argentina," Crop Breed Appl. Biotech., vol. 3, 203-208, 2008.

[10] J.H. Zhang, W.D. Huang, Y.P. Liu, Q.H. Pan, "Effect of temperature acclimation pretreatment on the ultra structure of mesophyll cells in young grape plants (Vitis vinifera) under cross temperature stresses," J. Integ. Plant. Bio., vol. 47, 959-970, 2005.

[11] J.L. Simoes-Araujo, N.G. Rumjanek, M. Margis-Pinheiro, "Small heat shock proteins genes are differentially expressed in distinct varieties of common bean," Braz. J. Plant Physiol., vol. 15, 33-41, 2003.

[12] P. Morales, J. Pace, J. Platt, T. Phillips, K. Morgan, A. Fazleabas, J. Hunt, "Placental cell expression of HLA-G2 isoforms is limited to the invasive trophoblast phenotype," $J$ Immunol, vol. 171, 6215-6224, 2003.

[13] A.I. Cabanero, Y. Madrid, C. Camara, "Selenium and mercury bioaccessibility in fish samples: an in vitro digestion method," Analytica Chimica Acta, vol. 526, 51-61,
2004.

[14] P.D. Hare, W. Cresss, "A metabolic implication of stressinduced proline accumulation in plants," Plant growth regulation., vol. 21, 79-102, 1998.

[15] A. Sakamoto, N. Murata, "The role of glycine betaine in the protection of plants from stress: clues from transgenic plants," Plant Cell Environ., vol. 25, 163-171, 2002.

[16] V.E Sharkova, "The effect of heat shock on the capacity of wheat plants to restore their photosynthetic electron transport after photoinhibition or repeated heating," Russ $J$ Plant Physiol, vol. 48, 793-97, 2001.

[17] R. Mittler, "Oxidative stress, antioxidants and stress tolerance," Trends Plant Sci., vol. 7, 405-410, 2002.

[18] M. Almeselmani, P.S. Deshmukh, R.K. Sairam, S.R. Kushwaha, T.P. Singh, "Protective role of antioxidant enzymes under high temperature stress," Plant Sci., vol.171, 382-388, 2006.

[19] F.V. Breusegem, E.Vranova, J.F Dat, D. Inze, "The role of active oxygen species in plant signal transduction," Plant Sci., vol. 161, 405-414, 2001.

[20] B. Asthir, A. Koundal, N.S. Bains, "Kinetic and thermodynamic behavior of wall-bound peroxidase from wheat leaves infected with stripe rust," Plant Growth Regul., vol. 59, 117-124, 2009.

[21] Le Roy Holm, J. Doll, E. H. Juan V, Pancho, P. James, Harberger, World Weeds: Natural histories and distribution, John Wiley and Sons. 67-69, 1997.

[22] S. Ignacimuthu, A. Jeyasankar N. Raja, "A process for the preparation of an active compound 2,5 diacetoxy-2-benzyl, 4,4,6,6-tetra methyl 1-1, 3-cyclohexanedione having insecticidal property, 579/CHE/2005, (Patent No. 236541)," Patentee: Entomology Research Institute., 2004.

[23] T. Bhakta, P.K. Mukherjee, K. Saha, M. Pal, B.P. Saha, "Studies on in vivo wound healing activity of Cassia fistula L. leaves (Fam. Leguminosae) in rats," Natural Product Sciences, vol. 4, 84-87, 1998.

[24] K.R. Kirtikar, B.D. Basu, "Indian Medicinal Plants" International book distributors, vol. 2, 856-860, 2006.

[25] J. Hutchinson, J.M. Dalziel, "Flora of West Tropical Africa, Second Edition, Vol. 1, Part 2. Crown Agents for Oversea Governments and Administrations, London. pp. 450-455, 1958.

[26] R. Prasanna, C. Harish, R. Pichai, D. Sakthisekaran, P. Gunasekaran, "Anti-cancer effect of Cassia auriculata leaf extract in vitro through cell cycle arrest and induction of apoptosis in human breast and larynx cancer cell lines," Cell Biol. Int., vol 33,127-134, 2009.

[27] P. Manickam, N. Namasivayam, V. Periyasamy, S.K. Rajagopal, "Effect of Cassia auriculata leaf extract on lipids in rats with alcoholic liver injury," Asia Pacific Journal of Clinical Nutrition., vol. 11, 157-163, 2002.

[28] International Rules for Seed Testing. ISTA, Seed Science \& Technology. vol.13, 299-335, 1985.

[29] D.T Arnon, "Copper enzymes in isolated chloroplast polyphenol oxidase in Beta vulgaris," Plant Physiol. vol. 24, $1-15,1949$. 
[30] O.H. Lowry, N.J. Rosebrough, A.L. Farr, R.J. Randall, "Protein measurement with Folin- Phenol reagent," J. Biol. Chem. vol. 193, 265-275, 1951.

[31] S. Ranganna, Handbook of analysis and quality control for fruit and vegetable products. $2^{\text {nd }}$ Edn. Tata Mc Graw Hill Publication Co. ltd, New Delhi, 1986.

[32] K.B. Kumar, P.A. Khan, "Peroxidase and polyphenol oxidase in excised Ragi (Eleusine coracana cv. PR 202) leaves during senescence," Ind J Exp Bot., vol. 20, 412-416, 1982.

[33] J.M. Chandlee, J.G. Scandalios, "Analysis of variants affecting the catalase development program in maize scutellum," Theor Appl Genet. vol. 69, 71-77, 1984.

[34] C. Beauchamp, I. Fridovich, Superoxide dismutase: improved assays and an assay applicable to acrylamide gels. Anal. Biochem. vol. 44, 276-287, 1971.

[35] T. Pasternak, V. Rudas, G. Potters, M.A.K. Jansen, "Morphogenic effects of abiotic stress: reorientation of growth in Arabidopsis thaliana seedlings, Environ. Exp. Bot, vol 53, 299-314, 2005.

[36] L.E. Williams, R. Lemonie, N. Saucer, Sugars transporters in higher plants: a diversity of roles and complex regulation trends, Plant Sci., vol. 5, 283-290, 2000.

[37] E.P. Murakeozy, Z. Nagy, C. Duhaze, A. Bouchereau, Z. Tuba, Seasonal changes in the levels of compatible osmolytes in three halophytic species of inland saline vegetation in Hungary, J. Plant Physiol., vol. 160, 395-401, 2003.

[38] H. Nayar, "Putrescine increases floral retention, pod set and seed yield in cold stressed chickpea," J Agron Crop Sci., vol. 191, 340-345, 2005.

[39] Z.Z. Xu, G.S Zhou, "Combined effects of water stress and high temperature on photosynthesis nitrogen metabolism and lipid peroxidation of a perennial grass Leymus chinensis," Planta., vol. 24, 1080-1090, 2006.
[40] M.T.P. Isabela, P.P.L Gluseppina, A. Henrique, O.G. Brasil, "Effect of $\mathrm{pH}$ on proline contents and peroxidise activity in metabolism of Sugarcane cultivated in vitro," Agronomia Trop. vol.53, 145-146, 2003.

[41] K. Lichtenthler, G. Langsdorf, S. Lenk, C. Buschamann, "Chlorophyll fluorescence imaging of photosynthetic activity with the flesh lamp fluorescence imaging system," Photosynthetic, vol. 43, 355-369, 2005.

[42] A. Gur, U. Demirel, M. Ozden, A. Kahraman, O. Copur, "Diurnal gradual heat stress affects antioxidant enzymes, proline accumulation and some physiological components in Cotton,” Afr. J. Biotechnol., vol 9, 1008-1015, 2010.

[43] G. Noctor, C.H. Foyer, "Ascorbate and glutathione: keeping active oxygen under control," Annu Rev of Plant Physiol Plant Mol Biol., vol. 49, 249-279, 1998.

[44] R.K Sairam, A. Tyagi, "Physiological and molecular biology of salinity stress tolerance in plants," Curr. Sci., vol. 86, 407-420, 2004

[45] J.G. Scandalios, Oxygen stress and superoxide dismutase, Plant Physiology., vol 101, 712-726, 1993.

[46] E. Esfandiari, F. Shekari, F. Shekari, M. Esfandiari, "The effect of salt stress on antioxidant enzymes activity and lipid peroxidation on the wheat seedling," Not. Bot. Hort. Agrobot. Cluj., vol. 35, 48-56, 2007.

[47] R. Nagesh Babu, V.R. Devaraj, "High temperature and salt stress response in French bean (Phaseolus vulgaris), " Aus. J. Crop Sci., vol. 2, 40-48, 2008.

[48] J.H. Dat, C.H. Foyer, I.M. Scott, "Changes in salicyclic acid and antioxidants during induced thermotolerance in mustard seedlings," Plant Physiol., vol 88, 1455-1461, 1998.

[49] S. Agarwal, V. Pandey, "Antioxidant enzyme response to $\mathrm{NaCl}$ stress in Cassia angustifolia," Biol. Plantarum., vol. 48, 555-560, 2004. 